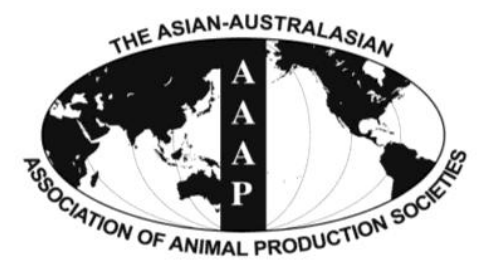

Asian-Aust. J. Anim. Sci.

Vol. 25, No. $6: 812$ - 817

June 2012

www.ajas.info

http://dx.doi.org/10.5713/ajas.2011.11383

\title{
Effect of Sodium Nitrate and Nitrate Reducing Bacteria on In vitro Methane Production and Fermentation with Buffalo Rumen Liquor
}

\author{
Pillanatham Civalingam Sakthivel, Devki Nandan Kamra, Neeta Agarwal and Lal Chandra Chaudhary* \\ Rumen Microbiology Laboratory, Animal Nutrition Division, \\ Indian Veterinary Research Institute, Izatnagar - 243122, India
}

\begin{abstract}
Nitrate can serve as a terminal electron acceptor in place of carbon dioxide and inhibit methane emission in the rumen and nitrate reducing bacteria might help enhance the reduction of nitrate/nitrite, which depends on the type of feed offered to animals. In this study the effects of three levels of sodium nitrate $(0,5,10 \mathrm{mM})$ on fermentation of three diets varying in their wheat straw to concentrate ratio (700:300, low concentrate, LC; 500:500, medium concentrate, MC and 300:700, high concentrate, HC diet) were investigated in vitro using buffalo rumen liquor as inoculum. Nitrate reducing bacteria, isolated from the rumen of buffalo were tested as a probiotic to study if it could help in enhancing methane inhibition in vitro. Inclusion of sodium nitrate at 5 or $10 \mathrm{mM}$ reduced ( $<<0.01)$ methane production (9.56, 7.93 vs. $21.76 \mathrm{ml} / \mathrm{g} \mathrm{DM} ; 12.20,10.42 \mathrm{vs.} 25.76 \mathrm{ml} / \mathrm{g} \mathrm{DM} ; 15.49,12.33 \mathrm{vs.} 26.86 \mathrm{ml} / \mathrm{g} \mathrm{DM}) \mathrm{in} \mathrm{LC}$, MC and $\mathrm{HC}$ diets, respectively. Inclusion of nitrate at both 5 and $10 \mathrm{mM}$ also reduced $(\mathrm{p}<0.01)$ gas production in all the diets, but in vitro true digestibility (IVTD) of feed reduced ( $\mathrm{p}<0.05$ ) only in LC and MC diets. In the medium at $10 \mathrm{mM}$ sodium nitrate level, there was 0.76 to $1.18 \mathrm{mM}$ of residual nitrate and nitrite $(\mathrm{p}<0.01)$ also accumulated. In an attempt to eliminate residual nitrate and nitrite in the medium, the nitrate reducing bacteria were isolated from buffalo adapted to nitrate feeding and introduced individually ( $3 \mathrm{ml}$ containing 1.2 to $2.3 \times 10^{6} \mathrm{cfu} / \mathrm{ml}$ ) into in vitro incubations containing the MC diet with $10 \mathrm{mM}$ sodium nitrate. Addition of live culture of NRBB 57 resulted in complete removal of nitrate and nitrite from the medium with a further reduction in methane and no effect on IVTD compared to the control treatments containing nitrate with autoclaved cultures or nitrate without any culture. The data revealed that nitrate reducing bacteria can be used as probiotic to prevent the accumulation of nitrite when sodium nitrate is used to reduce in vitro methane emissions. (Key Words: In vitro Gas Production, Methane, Nitrite, Nitrate Reducing Bacteria, Buffalo)
\end{abstract}

\section{INTRODUCTION}

Methane is a natural by product of feed fermentation in the rumen which accounts for a significant loss $(20$ to 120 $\mathrm{g} / \mathrm{kg}$ ) of the dietary energy consumed by ruminants (Johnson and Johnson, 1995). In the rumen, $\mathrm{CO}_{2}$ serves as a major terminal electron acceptor and is reduced to $\mathrm{CH}_{4}$ by the activity of methanogenic archaea (Wright and Pimm, 2003). In addition to $\mathrm{CO}_{2}$ there are other oxidized compounds which serve as terminal electron acceptors during fermentation of feeds in the rumen. Nitrate is one such alternate electron acceptor which can be reduced to ammonia via nitrite (Nakamura et al., 1975; Iwamoto et al., 2001). By addition of nitrate, methanogenesis is reduced thereby indicating that nitrate reducing bacteria can

\footnotetext{
* Corresponding Author: Lal Chandra Chaudhary. Tel: +915812301318, Fax: +91-5812301318, E-mail: lcchaudhary1@ rediffmail.com
}

Submitted Oct. 21, 2011; Accepted Dec. 28, 2011; Revised Jan. 30, 2012 compete with methanogens for hydrogen (Iwamoto et al., 2001; Kobayasi, 2010; Takahashi, 2011). Nitrate is reduced to ammonia through nitrite, but nitrite frequently accumulates in the rumen as reduction of nitrite to ammonia is slower than reduction of nitrate to nitrite (Iwamoto et al., 1999). Several bacteria (Selenomonas ruminantium, Veillonella parvula, Wolinella succinogenes) are capable of reducing nitrate in the rumen and, as a result, nitrite can accumulate to levels that can be toxic to the host (Dawson and Allison, 1988). A number of approaches have been investigated for their potential to prevent nitrite accumulation in the rumen including inoculation with Escherichia coli (Sar et al., 2006), inclusion of $\beta-1-4$ galacto-oligosaccharides or nisin (Sar et al., 2004) and addition of ethanol (Yoshii et al., 2005).

Our objective was to investigate comparative efficiency of nitrate with different diets to reduce methane production and to explore the possibility of using nitrate reducing bacteria, isolated from the rumen of nitrate adapted 
buffaloes, to prevent accumulation of nitrite in vitro.

\section{MATERIALS AND METHODS}

\section{Experiment 1: Effect of sodium nitrate on in vitro methane production}

Experimental design: Three diets, low concentrate (700 $\mathrm{g} / \mathrm{kg}$ wheat straw, WS $+300 \mathrm{~g} / \mathrm{kg}$ concentrate mixture, CM; LC), medium concentrate $(500 \mathrm{~g} / \mathrm{kg} \mathrm{WS}+500 \mathrm{~g} / \mathrm{kg} \mathrm{CM}$; MC) and high concentrate $(300 \mathrm{~g} / \mathrm{kg} \mathrm{WS}+700 \mathrm{~g} / \mathrm{kg} \mathrm{CM}$; $\mathrm{HC})$ were used as substrates. Concentrate mixtures consisted of maize grain, 320; solvent extracted soybean meal, 200; wheat bran, 450 ; a mineral mixture, 20 and salt, $10 \mathrm{~g} / \mathrm{kg}$ with chemical composition of OM, $895 \mathrm{~g}$; CP, 200 g; EE, $39 \mathrm{~g}$; NDF, $371 \mathrm{~g}$ and ADF, 157; hemicellulose, 214 and ash $105 \mathrm{~g} / \mathrm{kg}$ on DM basis. For each diet, three levels of sodium nitrate $(0,5,10 \mathrm{mM})$ in six replicates were examined using the in vitro procedure of Menke and Steingass (1988).

Preparation of inoculum: Rumen liquor was collected from two cannulated adult male Murrah buffaloes maintained on MC diet (6 kg feed per day in the morning). Rumen liquor was collected immediately before feeding using a metal probe covered with double layered filter mesh and transported in insulated flasks under anaerobic conditions. Rumen fluid from the two buffaloes was pooled in equal proportions and the mixture was used as inoculum.

In vitro gas production test: Wheat straw and $\mathrm{CM}$ were milled to pass a $1 \mathrm{~mm}$ sieve and $200 \mathrm{mg}$ was weighed into each $100 \mathrm{ml}$ syringe in a manner to obtain the desired WS:CM ratios for LC (700:300), MC (500:500) and HC (300:700) diets. The incubation medium (buffered rumen liquor) was prepared as described by Menke and Steingass (1988) and $30 \mathrm{ml}$ of medium was dispensed anaerobically to each syringe. Sodium nitrate from a stock solution was dispensed anaerobically to the glass syringes to achieve 0,5 and $10 \mathrm{mM}$ of nitrate in the medium. After recording the initial volume, the syringes were incubated at $39^{\circ} \mathrm{C}$ for $24 \mathrm{~h}$ with intermittent shaking at every $6 \mathrm{~h}$. Syringes without substrate were used as blanks.

Estimation of gas, methane, nitrate, nitrite and metabolites: After $24 \mathrm{~h}$ of incubation, the gas produced was measured by displacement of piston and corrected by subtracting the gas volume of a blank syringe to yield net gas produced due to substrate fermentation. For estimation of methane, $100 \mu \mathrm{l}$ of gas from the headspace of syringe was injected into a Nucon-5765 Gas Liquid Chromatograph equipped with a thermal conductivity detector and PorapakQ column (Agarwal et al., 2008). A mixture of $\mathrm{H}_{2}, \mathrm{CH}_{4}$ and $\mathrm{CO}_{2}(100 \mathrm{ml} / \mathrm{L}, 201 \mathrm{ml} / \mathrm{L}$ and $101 \mathrm{ml} / \mathrm{L}$, respectively) was used as a standard. After incubation, syringe contents were transferred into beakers and a sample of fermented liquid medium was used for estimation of metabolites. For estimation of nitrate and nitrite, fermented medium $(2 \mathrm{ml})$ was mixed with $2 \mathrm{ml}$ of $75 \mathrm{mM} \mathrm{ZnSO}{ }_{4}$ and $2.5 \mathrm{ml}$ of 55 $\mathrm{mM} \mathrm{NaOH}$. After $15 \mathrm{~min}$, samples were centrifuged at $2,500 \times \mathrm{g}$ for $10 \mathrm{~min}$ at $4^{\circ} \mathrm{C}$ to yield clear supernatant (Cortas and Wakid, 1990). In the supernatant, nitrate and nitrite were estimated by the procedure of Mir (2008). Lactic acid and ammonia $\mathrm{N}$ in the fermented medium were estimated as described by Barker and Summerson (1941) and Weatherburn (1967), respectively. A parallel set of syringes was incubated to estimate in vitro true digestibility (IVTD) of feed (Van Soest and Robertson, 1988). Microbial biomass production (MBM/100 mg digestible dry matter, DDM) was calculated as described by Makkar (2004).

\section{Experiment 2: Effect of nitrate reducing bacteria on in vitro methane emission}

Isolation of nitrate reducing bacteria: A modified Hungate (1969) anaerobic medium was used to isolate nitrate reducing bacteria. The medium contained $10 \mathrm{mM}$ $\mathrm{NaNO}_{3}, 40 \mathrm{mM}$ formic acid and $30 \mathrm{mM}$ each of fumaric and lactic acids (Asanuma et al., 2002; Yoshi et al., 2005). The $\mathrm{pH}$ of the medium was adjusted to 6.8 and anaerobically dispensed into roll tubes. For isolation of nitrate reducing bacteria, rumen liquor from an adult male Murrah buffalo adapted to nitrate feeding ( $0.5 \mathrm{~g}$ sodium nitrate $/ \mathrm{kg}$ of the $\mathrm{MC}$ diet) for 20 days, was inoculated to the specific medium. Isolation was done by repeated enrichment on selective medium and plating on solid medium and transferring isolated individual colonies into broth. Isolates were examined for Gram reaction, cell morphology and nitrate reducing ability. Microscopically the isolates were evaluated for purity and, in doubtful cases, the cultures were again serially diluted and plated on agar medium for re-isolation of discrete single colonies. Isolates were grown in the same broth as used for isolation and, after $24 \mathrm{~h}$ of incubation, nitrate reducing ability was assessed by measuring remaining nitrate using alpha napthalamine and sulfanilic acid (Quinn et al., 2001). Individual pure isolates were grown in Hungate medium for $24 \mathrm{~h}$ and used for in vitro gas production test.

In vitro gas production test with nitrate reducing bacteria: The medium and syringes were prepared as described in experiment 1 with the MC diet as substrate. The syringes containing substrate without any additive served as control. The syringes with substrate and $10 \mathrm{mM}$ sodium nitrate were used to examine the effect of nitrate inclusion. To estimate nitrate reducing capacity of the bacterial isolates, $3 \mathrm{ml}$ of live or autoclaved culture (1.2 to $2.3 \times 10^{6} \mathrm{cfu} / \mathrm{ml}$ ) of each isolate was added to the syringes containing substrate and $10 \mathrm{mM}$ sodium nitrate. Each treatment was replicated six times and analyses were done 
as described in experiment 1. Comparisons were made for each of the treatments with control.

\section{Statistical analysis}

The statistical analysis was done using factorial univariate ANOVA with contrast analysis using the model, intercept+diet+treatment+diet $\times$ treatment to analyze the effect of diet, treatment and their interaction and means were compared using Tukey's test if the main effect was significant (i.e., $\mathrm{p}<0.05$ ). For the second experiment one way ANOVA was used and means were compared using Tukey's test as per methods of SPSS (2002).

\section{RESULTS}

\section{Experiment 1}

In vitro gas production was significantly higher ( $\mathrm{p}<0.05$ ) with the HC and MC diets as compared to LC diet. There was gradual decrease in total gas production with the increasing level of nitrate irrespective of the diets (Table 1). Similarly methane production $(\mathrm{ml} / \mathrm{g} \mathrm{DM})$ was also higher with $\mathrm{HC}$ and MC diets as compared to LC diet but when expressed as $\mathrm{ml} / \mathrm{g}$ digested dry matter (DDM) the methane production was significantly lower with $\mathrm{HC}$ diet as compared to MC and LC diets. By inclusion of nitrate at 5 and $10 \mathrm{mM}$, methane production was reduced $(\mathrm{p}<0.001)$ in a dose dependent manner. The inhibition of in vitro methane production $(\mathrm{ml} / \mathrm{g} \mathrm{DDM})$ was maximum with the LC diet (54.71 and 60.24\%) and was the least with the HC diet (35.91 and $53.03 \%)$.

The in vitro true digestibility was the highest for $\mathrm{HC}$ diet, intermediate for MC and the lowest for LC diet (Table 1). Inclusion of nitrate in the medium reduced $(p<0.001)$ the IVTD of the LC and MC diets and the extent of inhibition was similar at both the levels of nitrate. Ammonia $\mathrm{N}$ in the medium was lower with the LC diet as compared to MC and $\mathrm{HC}$ diets. Inclusion of nitrate increased ammonia $\mathrm{N}$ irrespective of diet. Lactic acid production was similar in LC and MC diets but was higher $(\mathrm{p}<0.05)$ in $\mathrm{HC}$ diet and inclusion of nitrate at $10 \mathrm{mM}$ level decreased $(\mathrm{p}<0.001)$ lactic acid concentration in the medium irrespective of diet and reached to non-detectable levels in LC and MC diets. The reduction of nitrate was partial as residual nitrate was found in the fermented medium with all the three diets, however low nitrate residue in HC diet as compared to LC diet indicated faster reduction of nitrate with high concentrate diet. The nitrite produced by reduction of nitrate accumulated in the fermented medium at both the levels of nitrate inclusion and the level of accumulation of nitrite was similar in all the three diets (Table 1).

\section{Experiment 2}

A total of 75 bacteria capable of nitrate reduction were isolated from the rumen of one of our buffaloes adapted to nitrate feeding. Of these 75 isolates, 11 were selected for in vitro studies on the basis of their capacity to reduce nitrate and inhibit methanogenesis in comparison to rest of the isolates. The selected isolates were Gram negative and cocci in shape. The addition of $10 \mathrm{mM}$ nitrate alone resulted in a $69 \%$ (14.41 vs. 47.28$)$ reduction in methane production with a $14 \%$ reduction $(\mathrm{p}<0.05)$ in IVTD of feed. There was accumulation of residual nitrate and nitrite indicating partial reduction of these electron acceptors. Inclusion of autoclaved cultures did not effect methane production, however the level of residual nitrate and accumulation of nitrite was significantly reduced. Inclusion of live cultures of all the eleven isolates along with $10 \mathrm{mM}$ nitrate further reduced in vitro methane production except culture Nos. NRBB 13, and 65. The highest inhibition of $99 \%$ (0.47 vs. 14.41) by inclusion of live culture of NRBB 57 without any further reduction in IVTD was demonstrated. Nitrate and nitrite were undetectable once the medium was inoculated with NRBB 57 (Table 2). Though by inclusion of live culture of other isolates also, nitrate and nitrite were

Table 1. Effect of nitrate on feed fermentation in in vitro gas production test

\begin{tabular}{|c|c|c|c|c|c|c|c|c|c|c|c|c|c|}
\hline \multirow{4}{*}{ Parameter } & \multicolumn{9}{|c|}{ Substrate (Wheat straw:concentrate) } & \multirow{4}{*}{ SEM } & \multirow{2}{*}{\multicolumn{3}{|c|}{$\begin{array}{c}\text { Statistical significance } \\
\text { p value }\end{array}$}} \\
\hline & \multicolumn{3}{|c|}{$70: 30(\mathrm{LC})$} & \multicolumn{3}{|c|}{$50: 50(\mathrm{MC})$} & \multicolumn{3}{|c|}{$30: 70(\mathrm{HC})$} & & & & \\
\hline & \multirow[b]{2}{*}{0} & \multirow[b]{2}{*}{5} & \multirow[b]{2}{*}{10} & \multicolumn{3}{|c|}{ Level of nitrate $(\mathrm{mM})$} & \multirow[b]{2}{*}{0} & \multirow[b]{2}{*}{5} & \multirow[b]{2}{*}{10} & & \multirow[b]{2}{*}{ Diet } & \multirow[b]{2}{*}{ Treatment } & \multirow{2}{*}{$\begin{array}{c}\text { Diet } \\
\times \\
\text { Treatment }\end{array}$} \\
\hline & & & & 0 & 5 & 10 & & & & & & & \\
\hline Total gas (ml/g DM) & $139.9^{\mathrm{bc}}$ & $93.1^{\mathrm{ef}}$ & $83.7^{\mathrm{f}}$ & $161.9^{\mathrm{a}}$ & $111.9^{\mathrm{d}}$ & $106.5^{\text {de }}$ & $172.4^{\mathrm{a}}$ & $141.3^{\mathrm{b}}$ & $125.6^{\mathrm{c}}$ & 4.189 & 0.023 & 0.012 & 0.001 \\
\hline Methane (ml/g DM) & $21.76^{\mathrm{b}}$ & $9.56^{\mathrm{ef}}$ & $7.93^{\mathrm{f}}$ & $25.76^{\mathrm{a}}$ & $12.20^{\mathrm{d}}$ & $10.42^{\mathrm{de}}$ & $26.86^{\mathrm{a}}$ & $15.49^{\mathrm{c}}$ & $12.33^{\mathrm{d}}$ & 0.849 & 0.001 & 0.001 & 0.006 \\
\hline Methane (ml/g DDM) & $36.45^{\mathrm{a}}$ & $16.51^{\mathrm{de}}$ & $14.52^{\mathrm{e}}$ & $35.41^{\mathrm{a}}$ & $18.44^{\mathrm{cd}}$ & $15.12^{\mathrm{e}}$ & $31.38^{\mathrm{b}}$ & $20.11^{\mathrm{c}}$ & $14.74^{\mathrm{e}}$ & 1.296 & 0.088 & 0.001 & 0.001 \\
\hline IVTD (g/g) & 0.55 & 0.51 & 0.50 & 0.67 & 0.59 & 0.61 & 0.74 & 0.72 & 0.74 & 0.013 & 0.001 & 0.001 & 0.106 \\
\hline $\mathrm{NH}_{3}-\mathrm{N}(\mathrm{mg} / \mathrm{dl})$ & 9.00 & 10.90 & 11.24 & 10.61 & 12.20 & 11.96 & 11.57 & 12.90 & 12.87 & 0.187 & 0.001 & 0.001 & 0.580 \\
\hline MBM (g/g DDM) & 0.46 & 0.59 & 0.64 & 0.47 & 0.61 & 0.69 & 0.55 & 0.56 & 0.62 & 0.023 & 0.001 & 0.010 & 0.811 \\
\hline Lactic acid (mg/dl) & 0.80 & 0.61 & 0.00 & 0.81 & 0.67 & 0.00 & 1.30 & 0.84 & 0.11 & 0.101 & 0.036 & 0.001 & 0.601 \\
\hline Nitrite (mM) & 0.00 & 0.37 & 2.13 & 0.00 & 0.056 & 2.71 & 0.00 & 0.049 & 2.43 & 0.160 & 0.679 & 0.001 & 0.059 \\
\hline Nitrate (mM) & $0.00^{\mathrm{c}}$ & $0.100^{\mathrm{c}}$ & $1.18^{\mathrm{a}}$ & $0.00^{\mathrm{c}}$ & $0.094^{\mathrm{c}}$ & $1.08^{\mathrm{ab}}$ & $0.00^{\mathrm{c}}$ & $0.089^{\mathrm{c}}$ & $0.755^{\mathrm{b}}$ & 0.065 & 0.063 & 0.001 & 0.047 \\
\hline
\end{tabular}

Values are means of 6 replicates. ${ }^{\text {abcdef }}$ Different superscripts in row differ significantly. 
Table 2. Effect of inclusion of nitrate reducing bacteria on in vitro methane production, digestibility of feed and fermentation parameters

\begin{tabular}{|c|c|c|c|c|c|c|}
\hline & $\begin{array}{l}\text { Total gas } \\
\text { (ml/g DM) }\end{array}$ & $\begin{array}{c}\text { Methane } \\
(\mathrm{ml} / \mathrm{g} \text { DDM })\end{array}$ & $\begin{array}{l}\text { IVTD } \\
(g / g)\end{array}$ & $\begin{array}{l}\mathrm{NH}_{3} \mathrm{~N} \\
(\mathrm{mg} / \mathrm{dl})\end{array}$ & $\begin{array}{l}\text { Nitrite } \\
(\mathrm{mM})\end{array}$ & $\begin{array}{l}\text { Nitrate } \\
(\mathrm{mM})\end{array}$ \\
\hline Control & $155.63^{\mathrm{a}}$ & $47.28^{\mathrm{a}}$ & $0.66^{\mathrm{a}}$ & $17.55^{\mathrm{kl}}$ & $0.000^{f}$ & $0.000^{\mathrm{b}}$ \\
\hline $\mathrm{CN}$ & $83.59^{\mathrm{g}}$ & $14.41^{\text {cde }}$ & $0.57^{\text {bcd }}$ & $19.81^{b c}$ & $2.177^{\mathrm{a}}$ & $2.317^{\mathrm{a}}$ \\
\hline $\mathrm{CN}+\mathrm{NRBB}_{10} \mathrm{~A}$ & $111.09^{\text {bcdef }}$ & $11.72^{\text {cdefg }}$ & $0.56^{\text {bcd }}$ & $20.42^{\mathrm{b}}$ & $1.871^{\mathrm{a}}$ & $0.000^{\mathrm{b}}$ \\
\hline $\mathrm{CN}+\mathrm{NRBB}_{10} \mathrm{~L}$ & $95.25^{\text {defg }}$ & $2.73^{\mathrm{ij}}$ & $0.57^{\mathrm{bcd}}$ & $18.94^{\text {defghi }}$ & $0.176^{\mathrm{ef}}$ & $0.000^{\mathrm{b}}$ \\
\hline $\mathrm{CN}+\mathrm{NRBB}_{13} \mathrm{~A}$ & $120.03^{\mathrm{bcd}}$ & $14.20^{\text {cdef }}$ & $0.61^{\mathrm{ab}}$ & $19.91^{\mathrm{bcd}}$ & $0.915^{\mathrm{bcd}}$ & $0.146^{\mathrm{b}}$ \\
\hline $\mathrm{CN}+\mathrm{NRBB}_{13} \mathrm{~L}$ & $107.66^{\text {bcdefg }}$ & $10.69^{\text {efg }}$ & $0.59^{\mathrm{bcd}}$ & $18.74^{\text {fghi }}$ & $0.004^{\mathrm{f}}$ & $0.199^{\mathrm{b}}$ \\
\hline $\mathrm{CN}+\mathrm{NRBB}_{23} \mathrm{~A}$ & $109.34^{\text {bcdef }}$ & $11.98^{\text {cdefg }}$ & $0.55^{\mathrm{bcd}}$ & $17.82^{\mathrm{jkl}}$ & $1.032^{\mathrm{b}}$ & $0.000^{\mathrm{b}}$ \\
\hline $\mathrm{CN}+\mathrm{NRBB}_{23} \mathrm{~L}$ & $86.39^{\mathrm{fg}}$ & $2.75^{\mathrm{ij}}$ & $0.56^{\text {bcd }}$ & $18.34^{\text {hijk }}$ & $0.198^{\mathrm{ef}}$ & $0.000^{\mathrm{b}}$ \\
\hline $\mathrm{CN}+\mathrm{NRBB}_{32} \mathrm{~A}$ & $109.37^{\text {bcdef }}$ & $11.11^{\text {defg }}$ & $0.52^{\mathrm{d}}$ & $18.08^{\mathrm{ijk}}$ & $0.917^{\mathrm{bcd}}$ & $0.000^{\mathrm{b}}$ \\
\hline $\mathrm{CN}+\mathrm{NRBB}_{32} \mathrm{~L}$ & $95.19^{\text {defg }}$ & $1.28^{\mathrm{j}}$ & $0.54^{\mathrm{cd}}$ & $18.43^{\text {ghijk }}$ & $0.007^{\mathrm{f}}$ & $0.000^{\mathrm{b}}$ \\
\hline $\mathrm{CN}+\mathrm{NRBB}_{43} \mathrm{~A}$ & $128.12^{\mathrm{b}}$ & $18.99^{\mathrm{bc}}$ & $0.62^{\mathrm{ab}}$ & $19.74^{\text {bcdef }}$ & $0.923^{\text {bcd }}$ & $0.172^{\mathrm{b}}$ \\
\hline $\mathrm{CN}+\mathrm{NRBB}_{43} \mathrm{~L}$ & $110.27^{\text {bcdef }}$ & $9.14^{\text {fghi }}$ & $0.58^{\mathrm{bcd}}$ & $19.24^{\text {cdefgh }}$ & $0.004^{\mathrm{f}}$ & $0.160^{\mathrm{b}}$ \\
\hline $\mathrm{CN}+\mathrm{NRBB}_{45} \mathrm{~A}$ & $103.13^{\text {bcdefg }}$ & $10.24^{\text {efgh }}$ & $0.56^{\text {bcd }}$ & $19.43^{\text {bcdefg }}$ & $0.974^{\mathrm{bc}}$ & $0.000^{\mathrm{b}}$ \\
\hline $\mathrm{CN}+\mathrm{NRBB}_{45} \mathrm{~L}$ & $101.45^{\text {cdefg }}$ & $3.37^{\text {hij }}$ & $0.55^{\mathrm{bcd}}$ & $18.81^{\text {efghij }}$ & $0.001^{\mathrm{f}}$ & $0.000^{\mathrm{b}}$ \\
\hline $\mathrm{CN}+\mathrm{NRBB}_{57 \mathrm{~A}}$ & $103.15^{\text {bcdefg }}$ & $14.66^{\text {cdef }}$ & $0.54^{\mathrm{cd}}$ & $19.48^{\text {bcdefg }}$ & $0.743^{\text {bcd }}$ & $0.000^{\mathrm{b}}$ \\
\hline $\mathrm{CN}+\mathrm{NRBB}_{57} \mathrm{~L}$ & $94.21^{\mathrm{efg}}$ & $0.47^{\mathrm{j}}$ & $0.53^{\mathrm{cd}}$ & $18.73^{\text {fghi }}$ & $0.000^{f}$ & $0.000^{\mathrm{b}}$ \\
\hline $\mathrm{CN}+\mathrm{NRBB}_{60} \mathrm{~A}$ & $121.58^{b c}$ & $22.29^{\mathrm{b}}$ & $0.56^{\mathrm{bcd}}$ & $17.98^{\mathrm{ijk}}$ & $0.449^{\mathrm{bcd}}$ & $0.171^{\mathrm{b}}$ \\
\hline $\mathrm{CN}+\mathrm{NRBB}_{60} \mathrm{~L}$ & $117.99^{\text {bcde }}$ & $11.61^{\text {cdefg }}$ & $0.59^{\mathrm{bcd}}$ & $17.00^{1}$ & $0.000^{\mathrm{f}}$ & $0.180^{\mathrm{b}}$ \\
\hline $\mathrm{CN}+\mathrm{NRBB}_{65} \mathrm{~A}$ & $113.79^{\text {bcde }}$ & $17.84^{\text {bcde }}$ & $0.60^{\mathrm{abc}}$ & $20.30^{\mathrm{bc}}$ & $0.382^{\text {cdef }}$ & $0.156^{\mathrm{b}}$ \\
\hline $\mathrm{CN}+\mathrm{NRBB}_{65} \mathrm{~L}$ & $122.70^{\mathrm{bc}}$ & $15.37^{\text {bdef }}$ & $0.61^{\mathrm{ab}}$ & $19.86^{\text {bcde }}$ & $0.004^{\mathrm{f}}$ & $0.151^{\mathrm{b}}$ \\
\hline $\mathrm{CN}+\mathrm{NRBB}_{73} \mathrm{~A}$ & $116.44^{\text {bcde }}$ & $13.89^{\text {cdef }}$ & $0.57^{\mathrm{bcd}}$ & $19.88^{\text {bcde }}$ & $1.916^{\mathrm{a}}$ & $0.000^{\mathrm{b}}$ \\
\hline $\mathrm{CN}+\mathrm{NRBB}_{73} \mathrm{~L}$ & $97.86^{\text {cdeg }}$ & $1.06^{\mathrm{j}}$ & $0.57^{\mathrm{bcd}}$ & $19.31^{\text {cdefgh }}$ & $0.048^{\mathrm{f}}$ & $0.010^{\mathrm{b}}$ \\
\hline $\mathrm{CN}+\mathrm{NRBB}_{75} \mathrm{~A}$ & $121.79^{\mathrm{bc}}$ & $18.59^{\mathrm{bcd}}$ & $0.58^{\mathrm{bcd}}$ & $21.45^{\mathrm{a}}$ & $0.314^{\mathrm{def}}$ & $0.157^{\mathrm{b}}$ \\
\hline $\mathrm{CN}+\mathrm{NRBB}_{75} \mathrm{~L}$ & $100.51^{\text {cdefg }}$ & $2.50^{\mathrm{ij}}$ & $0.58^{\mathrm{bcd}}$ & $19.87^{\text {bcde }}$ & $0.000^{\mathrm{f}}$ & $0.153^{\mathrm{b}}$ \\
\hline SEM & 1.966 & 1.175 & 0.004 & 0.125 & 0.081 & 0.0552 \\
\hline
\end{tabular}

Values are means of 6 replicates. $\mathrm{CN}=\mathrm{Control}+10 \mathrm{mM}$ nitrate. NRBB isolates-A (autoclaved culture), NRBB isolates-L (live culture).

abcdefghij Different superscripts in a column differ $(\mathrm{p}<0.05)$.

undetectable in the medium but methane inhibition was not at the level $99 \%$ as with NRBB57.

\section{DISCUSSION}

The results of experiment 1 demonstrate that the high ratio of concentrate in $\mathrm{MC}$ and $\mathrm{HC}$ diets was responsible for significantly higher gas production as compared to LC diet accompanied with lesser methane emissions ( $\mathrm{ml} / \mathrm{g}$ DDM). It is well known that an increase in rapidly fermentable carbohydrates in diet decreases methane emissions per unit feed digested (Beauchemin et al., 2008). Inclusion of nitrate resulted in a decrease in in vitro methane emission irrespective of diet. In vitro and in vivo inhibition of methanogenesis by using nitrate as electron acceptor has also been reported earlier (Takahashi and Young, 1991; Sar et al., 2004). In the present study nitrate was more effective in suppressing $\mathrm{CH}_{4}$ production on a high forage diet (54.71 and $60.24 \%$ vs. 35.91 and $53.03 \%$ inhibition with LC and $\mathrm{HC}$ diets). Such an effect might be due to many reasons, but the higher numbers of nitrate reducing bacteria might be one of the most important factors as also reported by
Asanuma et al. (2002) that the population density of Wollinella succinogenes and Veillonella parvula, two important nitrate reducing ruminal bacteria, increased by changing goats from a high concentrate to a high forage diet. Iwamoto et al. (2001) also found that feeding goats a high forage diet increased nitrate and nitrite reducing capacity of the rumen. Reduction in methane production under in vitro condition due to nitrate and nitrite addition was also reported by Lin et al. (2011).

An increase in ammonia $\mathrm{N}$ in rumen fluid of sheep fed a mixed diet of timothy hay, alfalfa hay and concentrate (400:400:200) with nitrate at $1.3 \mathrm{~g} \mathrm{NaNO}_{3} / \mathrm{kg}^{0.75}$ has also been reported (Sar et al., 2004). Inclusion of nitrate in the medium resulted in an accumulation of nitrite and residual nitrate in all the treatments. Burrows et al. (1987) suggested that increasing the level of concentrate in diet enhances bacterial utilization of ammonia $\mathrm{N}$, and that the resulting lower levels of ammonia in turn limits accumulation of nitrite in the rumen. With buffalo rumen liquor as inoculum and by inclusion of nitrate, the lactic acid level in the fermented medium decreased with increasing the concentration of nitrate. Lactate producing bacteria appear 
to perform an important role in nitrate/nitrite reduction. The production of lactate by these bacteria suppresses methanogenesis as lactate can serve as an electron acceptor as well as increase the activity of nitrate reducing bacteria which utilize lactate as a substrate (Iwamoto et al., 2001). This may explain why methane and lactate production were both reduced with inclusion of nitrate in the medium. Our results indicate that nitrate suppresses methanogenesis, but the levels used in our experiment resulted in accumulation of nitrate and nitrite in the fermented medium as a result of partial reduction of nitrate to nitrite and to ammonia. Presence of nitrite in the rumen is toxic for the animal as it enters in to the blood and converts hemoglobin into methemoglobin (McAllister et al., 1996). Therefore while using nitrate as an alternate electron acceptor to reduce methanogenesis, care has to be taken to avoid nitrite accumulation.

Therefore, to enhance the reduction of nitrate to nitrite and to ammonia, another experiment was conducted using live cultures of nitrate reducing bacteria isolated from buffalo rumen. The level of residual nitrate and accumulation of nitrite was significantly reduced without any change in methane production even by inclusion of autoclaved cultures. The reason for this reduction by inclusion of autoclaved culture can only be explained on the basis of assumption that there might be some unknown factors in the culture medium which were responsible for such reduction in residual nitrate and accumulation of nitrite. Inoculation of live culture of NRBB 57 along with $10 \mathrm{mM}$ nitrate resulted in maximum reduction of $99 \%$ in methanogenesis among the isolates, with complete absence of nitrate and nitrite in the medium. Increasing the population density of nitrate reducing bacteria in the presence of nitrate has previously been shown to be an effective means of inhibiting methanogenesis (Iwamoto et al., 2002). Addition of nitrate to the diet of sheep, along with nitrate-reducing E. coli (Sar et al., 2006) or with $\beta-1-4$ galacto-oligosaccharides (Sar et al., 2004) has been shown to reduce nitrite accumulation in the rumen, but a further reduction in methane production was not detected. This response differs from ours, where we observed a further decline in methanogenesis as a result of addition of nitrate reducing bacteria. In addition to that inoculated isolates prevented accumulation of nitrite, suggesting that they might also provide protection against nitrite toxicity when nitrate is used as a method of lowering methane production in the rumen.

\section{CONCLUSION}

Nitrate inclusion in the incubation medium reduced in vitro methanogenesis by $69 \%$ accompanied by a $14 \%$ depression in IVTD. Methane reduction was enhanced to
$99 \%$ in relation to control without any further adverse effect on IVTD of feed by adding a live culture of NRBB 57 to a MC diet. Among 11 bacterial isolates, NRBB 57 exhibited the highest nitrate and nitrite reducing capacity as there was no residual nitrate or nitrite remaining in the incubation medium. Therefore, a combination of nitrate and NRBB 57 might prove useful as a means to reduce methanogenesis in ruminants after standardizing the in vivo dose to achieve maximum methane inhibition without adverse effects on diet digestibility.

\section{ACKNOWLEDGEMENTS}

Financial assistance provided to the senior author in the form of a fellowship by the Director, Indian Veterinary Research Institute, Izatnagar, India and research grant provided by NAIP, ICAR, India are gratefully acknowledged.

\section{REFERENCES}

Agarwal, N., D. N. Kamra, P. N. Chatterjee, R. Kumar and L. C. Chaudhary. 2008. In vitro methanogenesis, microbial profile and fermentation of green forages with buffalo rumen liquor as influenced by 2-bromoethanesulphonic acid. Asian-Aust. J. Anim. Sci. 21:818-823.

Asanuma, N., M. Iwamoto, M. Kawato and T. Hino. 2002. Numbers of nitrate reducing bacteria in the rumen as estimated by competitive polymerase chain reaction. Anim. Sci. J. 73: 199-205.

Barker, S. B. and W. H. Summerson. 1941. The colorimetric determination of lactic acid in biological materials. J. Biol. Chem. 138:535.

Beauchemin, K. A., M. Kreuzer, F. O'Mara and T. A. McAllister. 2008. Nutritional management for enteric methane abatement: a review. Aust. J. Exp. Agric. 48:21-27.

Burrows, G. E., G. W. Horn, R. W. McNew, L. I. Croy, R. D. Keeton and J. Kyle. 1987. The prophylactic effect of corn supplementation on experimental nitrate intoxication in cattle. J. Anim. Sci. 64:1682-1689.

Cortas, N. K. and N. W. Wakid. 1990. Determination of inorganic nitrate in serum and urine by kinetic cadmium reduction method. Clin. Chem. 36:1440-1443.

Dawson, K. A. and M. J. Allison. 1988. Digestive disorders and nutritional toxicity. In: The Rumen Microbial Eco-system (Ed. P. N. Hobson), pp. 445-459. Elsevier Applied Science, London (UK) and New York (NY, USA).

Hungate, R. E. 1969. A roll tube method for cultivation of strict anaerobes, In: Methods in Microbiology (Ed. I. R. Norris and E. W. Robons). 3:117-132.

Iwamoto, M., N. Asanuma and T. Hino. 1999. Effects of nitrate combined with fumarate on methanogenesis, fermentation and cellulose digestion by mixed ruminal microbes in in vitro. Anim. Sci. J. 70:471-478.

Iwamoto, M., N. Asanuma and T. Hino. 2002. Ability of Selenomonas ruminantium, Veillonella parvula and Wolinella succinogenes to reduce nitrate and nitrite with special 
reference to the suppression of ruminal methanogenesis. Anaerobe 8:209-215.

Iwamoto, M., N. Asanuma and T. Hino. 2001. Effects of pH and electron donors on nitrate and nitrite reduction in ruminal microbiota. Anim. Sci. J. 72:117-125.

Johnson, K. A. and D. E. Johnson. 1995. Methane emission from cattle. J. Anim. Sci. 73:2483-2492.

Kobayashi, Y. 2010. Abatement of methane production from ruminants: Trends in the manipulation of rumen fermentation. Asian-Aust. J. Anim. Sci. 23:410-416.

Lin, M., D. M. Schaefer, W. S. Guo, L. P. Ren and Q. X. Meng. 2011. Comparisons of in vitro nitrate reduction, methanogenesis, and fermentation acid profile among rumen bacterial, protozoal and fungal fractions. Asian-Aust. J. Anim. Sci. 24:471-478.

Makkar, H. P. S. 2004. Recent advances in the in vitro gas method for evaluation of nutritional quality of feed resources in assessing quality and safety of animal feeds FAO Animal Production and Health Paper 160. Food and Agriculture Organization of the United Nations, Rome.

McAllister, T. A., E. K. Okine, G. W. Mathison and K. J. Cheng. 1996. Dietary, environmental and microbiological aspects of methane production in ruminants. Can. J. Anim. Sci. 76:231243.

Menke, K. H. and H. Steingass. 1988. Estimation of energetic feed value obtained from chemical analysis and gas production using rumen fluid. Anim. Res. Dev. 28:7-55.

Mir, S. A. 2008. A rapid technique for determination of nitrate and nitric acid by acid reduction and diazotization at elevated temperature. Anal. Chim. Acta 620:183-189.

Nakamura, Y., J. Yoshida, R. Nakamura and H. Horie. 1975. Nitrate metabolism of microorganisms in the rumen of sheep fed high nitrate forages. Japan J. Zootech. Sci. 47:63-67.
Quinn, P. J., M. E. Carter, B. K. Markey and G. R. Carter. 2001. Clinical veterinary microbiology, MPG books Ltd, Bodmin, Cornwall, Great Britain.

Sar, C., B. Mwenya, B. Pen, K. Takaura, R. Morikawa, A. Tsujimoto, N. Isogai, Y. Asakura, I. Shinzato, Y. Toride and J. Takahashi. 2006. Effect of Escherichia coli W3110 or Escherichia coli nar-Ptac on methane emission and nitrate toxicity in nitrate treated sheep. Int. Congr. Ser. 1293:193-196.

Sar, C., B. Santoso, B. Mwenya, Y. Gamo, T. Kobayashi, R. Morikawa, K. Kimura, H. Mizukoshi and J. Takahashi. 2004. Manipulation of rumen methanogenesis by the combination of nitrate with $\beta$ 1-4 galacto-oligosaccharides or nisin in sheep. Anim. Feed Sci. Technol. 115:129-142.

SPSS, 2002. SPSS for Windows, Network version 11.5.1., SPSS Inc., Chicago, IL, USA.

Takahashi, J. 2011. Some prophylactic options to mitigate methane emission from animal agriculture in Japan. Asian-Aust. J. Anim. Sci. 24:285-294.

Takahashi, J. and B. A. Young. 1991. Prophylactic effect of Lcysteine on nitrate-induced alteration in respiratory exchange and metabolic rate in sheep. Anim. Feed Sci. Technol. 35:105113.

Van Soest, P. J. and J. B. Robertson. 1988. A laboratory manual for animal science. Vol 612, Cornell University, USA.

Weatherburn, M. W. 1967. Estimation of ammonia nitrogen by colorimetric method. Anal. Chem. 39:971-974.

Wright, A. D. G. and C. Pimm. 2003. Improved strategy for presumptive identification of methanogens using $16 \mathrm{~S}$ riboprinting. J. Microbiol. Methods 55:337-349.

Yoshii, T., N. Asanuma and T. Hino. 2005. Effect of ethanol on nitrate and nitrite reduction and methanogenesis in the ruminal microbiota. Anim. Sci. J. 76:37-42. 